\title{
Upstream elements required for efficient transcription of a human U6 RNA gene resemble those of $U 1$ and $U 2$ genes even though a different polymerase is used
}

\author{
Gary R. Kunkel and Thoru Pederson \\ Cell Biology Group, Worcester Foundation for Experimental Biology, Shrewsbury, Massachusetts 01545 USA
}

\begin{abstract}
U6 small nuclear RNA is transcribed by a different polymerase than U1-U5 RNAs, likely to be RNA polymerase III. Transcription from human U6 gene deletion-substitution templates in a HeLa S100 extract delineated the $5^{\prime}$ border of a control element lying between 67 and 43 bp upstream from the initiation site. This region matches the location of, and shows considerable sequence similarity with, the proximal control element of U1 and U2 RNA genes, which are transcribed by RNA polymerase II. Transfection of human 293 cells with 5 'flanking deletion-substitution mutants of a U6 maxigene revealed a dominant control element between 245 and 149 bp upstream of the transcription start site. An octamer motif was found in this region in an inverted orientation relative to that of the human U1 and U2 RNA gene enhancers but in the same orientation as a human U4 RNA gene, the transcript of which functions together with U6 RNA in a single small nuclear ribonucleoprotein (snRNP) particle. The human U2 gene enhancer joined to the U6 maxigene was able to functionally replace the $\mathrm{U} 6$ distal control element(s).
\end{abstract}

[Key Words: RNA polymerase III; snRNA genes; octamer motif]

Received September 14, 1987; revised version accepted January 5, 1988.

The abundant nucleoplasmic small nuclear RNAs (snRNAs) are integrated into ribonucleoprotein complexes (snRNPs) that serve as cofactors for mRNA processing reactions (Maniatis and Reed 1987; Sharp 1987). The biosynthesis of snRNPs is itself complex, with several features different from mRNA transcription and processing. U1, U2, U4, and U5 RNAs are transcribed by polymerase II but, unlike most polymerase II transcripts (mRNA), are capped with trimethylguanosine (Ro-Choi et al. 1976; Jensen et al. 1979; Roop et al. 1981; Kunkel and Pederson 1985). We and others have recently demonstrated that U6 RNA is transcribed by a different enzyme which, by the criteria of $\alpha$-amanitin sensitivity and competition for $5 S$ gene transcription machinery, is likely to be RNA polymerase III (Kunkel et al. 1986; Reddy et al. 1987). U6 RNA is also unusual in that its $5^{\prime}$ terminus is blocked by an undetermined structure (Epstein et al. 1980) and that it is dimerized with U4 RNA in a single RNP particle (Bringmann et al. 1984; Hashimoto and Steitz 1984; Rinke et al. 1985).

Studies of U1 and U2 RNA genes have revealed at least two major transcription control elements in their 5 '-flanking regions (Murphy et al. 1982; Skuzeski et al. 1984; Westin et al. 1984a; Ciliberto et al. 1985; Krol et al. 1985; Mattaj et al. 1985; Murphy et al. 1987b). One is located between 50 and 60 nucleotides upstream of these genes and regulates both transcription level and accurate selection of the initiation site (Skuzeski et al. 1984). The other is situated at about -220 nucleotides and acts as an enhancer (Mattaj et al. 1985; Mangin et al. 1986; Ares et al. 1987; Ciliberto et al. 1987). Lying within this enhancer is a copy of the so-called 'octamer motif', an element present in many polymerase II promoters and enhancers (Falkner and Zachau 1984; Parslow et al. 1984; Mattaj et al. 1985; Sive and Roeder 1986).

As a polymerase III transcript (Kunkel et al. 1986; Reddy et al. 1987), we expected the U6 RNA gene to contain fundamentally different control elements than those of U1 and U2 RNA genes. Indeed, the human U6 gene contains an internal sequence that is similar to a typical polymerase III intragenic control region, namely the 'A block' consensus of eukaryotic tRNA genes. However, there is also a TATA sequence at approximately -30 nucleotides in human, mouse, Xenopus, and Drosophila U6 genes (Kunkel et al. 1986; Das et al. 1987; Krol et al. 1987; Reddy et al. 1987). In fact, the entire 50 nucleotides upstream of these genes is highly conserved among these two mammals, suggesting that this region is functionally important.

Here we describe two major regions that control transcription for the human U6 RNA gene, both of which lie farther upstream of this proximal ( $\sim 50$ nucleotides) block of conserved sequences. Within these regions are 
domains that resemble, both in their position and sequence, the upstream control elements utilized by U1 and U2 RNA genes. Moreover, we find that the human U2 gene enhancer can functionally replace the distal control region of the human U6 gene.

\section{Results}

Maximum in vitro transcription of U6 RNA requires a 5' proximal control element

We previously noted that human and mouse U6 RNA genes contain a significant region of homology in the immediate 5'-flanking DNA, including a TATA sequence (See Fig. 1) that is also present in a similar position adjacent to Xenopus and Drosophila U6 genes (Das et al. 1987; Krol et al. 1987) and a human 7SK RNA gene (Murphy et al. 1986). To investigate the possible transcriptional importance of this region, a series of deletion-substitution clones were constructed in which the 5 '-flanking region of the human U6 gene was progressively deleted (Fig. 2A). Transcription of each DNA in a HeLa cell S100 extract (Weil et al. 1979) yielded the RNAs shown in Figure $2 \mathrm{~B}$. We have shown previously that transcription of the human U6 gene in an S100 extract displayed $\alpha$-amanitin sensitivity characteristic of a polymerase III product (Kunkel et al. 1986). Whereas templates containing 67 bp or more of $5^{\prime}$-flanking sequence supported the synthesis of U6 RNA, transcription was markedly inhibited with templates containing $43 \mathrm{bp}$ or less of 5 -flanking DNA. The complex pattern of larger RNAs present in each lane of Figure $2 \mathrm{~B}$ is a consequence of transcription of plasmid vector sequences (results not shown). The definitive quantitation of U6 RNA is thus shown by the results of hybrid selection with M13/U6 DNA (Fig. 2C); note that this drastically reduces the amount of the larger plasmid transcripts (cf. Fig. 2B).

The most straightforward interpretation of the $\$ 100$ transcription results is that the $5^{\prime}$ border of a control element is located between -67 and -43 bp relative to the U6 RNA transcription start site. However, it is possible that the substitution by plasmid vector sequences brought a negative control element close to the U6 gene. To test this latter possibility, two mutant U6 templates were constructed in which a limited segment of vicinal $5^{\prime}$-flanking sequence was deleted and replaced by an XhoI linker, leaving the majority of the human upstream region intact (U6/dl $-55,-1$ and $\mathrm{U} 6 / \mathrm{dl}-28,-13)$. In vitro transcription of U6 RNA from these templates was also very much inhibited when compared to the parent pGEM/U6 plasmid (Fig. 2D). It is therefore improbable that a negative influence by plasmid vector sequences is responsible for the effect seen with the deletion-substitution constructions (Fig. 2). Thus, these results indicate that a positive control element lies within 67 nucleotides of the U6 transcription start site.

A comparison of the U6 gene's 5'-flanking sequence in this region with that of human $\mathrm{U} 1$ and $\mathrm{U} 2$ RNA genes shows $50-67 \%$ similarity (Fig. 3). The proximal control

\begin{tabular}{|c|c|c|c|c|}
\hline & AAGGT & CGGGCAGGAA & GAGGGCCTAT & -241 \\
\hline-240 & TTCCCATGAT & TCCTTCATAT & TTGCATATAC & -211 \\
\hline-210 & GATACAAGGC & TGTTAGAGAG & ATAATTAGAA & -181 \\
\hline-180 & TTAATTTGAC & TGTAAACACA & AAGATATTAG & -151 \\
\hline-150 & TACAAAATAC & GTGACGTAGA & AAGTAATAAT & -121 \\
\hline-120 & TTCTTGGGTA & GTTTGCAGTT & TTTAAAATTA & -91 \\
\hline-90 & TGTIITAAAA & TGGACTATCA & TATGCTTACC & -61 \\
\hline-60 & GTAACTTGAA & AGTATTTCGA & TTTCTTGGCT & -31 \\
\hline-30 & TrATATATCT & TGTGGAAAGG & ACGAAACACC & -1 \\
\hline+1 & GTGCTCGCTT & CGGCAGCACA & TATACTAAAA & +30 \\
\hline+31 & TTGGAACGAT & ACAGAGAAGA & TTAGCATGEC & +60 \\
\hline+61 & CCCTGCGCAA & GGATGACACG & CAAATTCGTG & +90 \\
\hline+91 & AAGCGTTCCA & TATTTITACA & TCAGGTTGTT & +120 \\
\hline+121 & TTTCTGTTTT & TACATCAGGT & TGTTTTTCTG & +150 \\
\hline+151 & TTTGGTTITT & TITTTACACC & ACGTTTATAC & +180 \\
\hline+181 & GCCGGTGCAC & GGTTTACCA & & \\
\hline
\end{tabular}

Figure 1. Sequence of a human U6 RNA gene locus. Sequencing of U6 homologous and flanking regions was carried out using the dideoxy method on recombinant M13 or doublestranded templates in pGEM vectors. The underlined region corresponds to the sequence of mature U6 RNA. The boxed regions are discussed in the text.

element known to be important for U1 and U2 RNA transcription lies within this area of sequence similarity to the U6 gene's flanking sequence (Skuzeski et al. 1984; Westin et al. 1984a). Thus, there is a correspondence between the sequence and location of a functional U6 RNA transcription control element and one used by polymerase II on U1 and U2 RNA genes.

\section{U6 RNA genes use a distal control element in vivo}

Prompted by the foregoing in vitro results, we used transient expression of transfected human U6 RNA genes to investigate the requirement for $5^{\prime}$-flanking sequences in vivo. A U6 RNA maxigene was constructed by insertion of an Xhol linker after position 87 of the transcribed U6 sequence (Fig. 4).

Transcription of this maxigene produces a U6 RNA molecule that is 9 nucleotides longer than endogenous U6 RNA /8 nucleotides for the XhoI linker +1 nucleotide for the cytosine at position 87 , which was duplicated in the subcloning procedurel. A series of deletion- 
A pGEM / U6

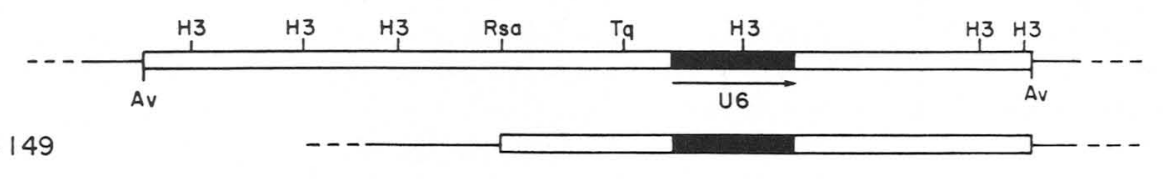

$\cup 6 / 5^{\prime}-149$

บ $6 / 5^{\prime}-67$
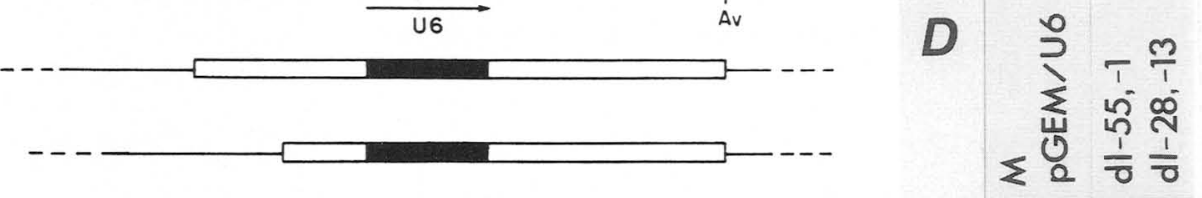

U $6 / 5^{\prime}-43$
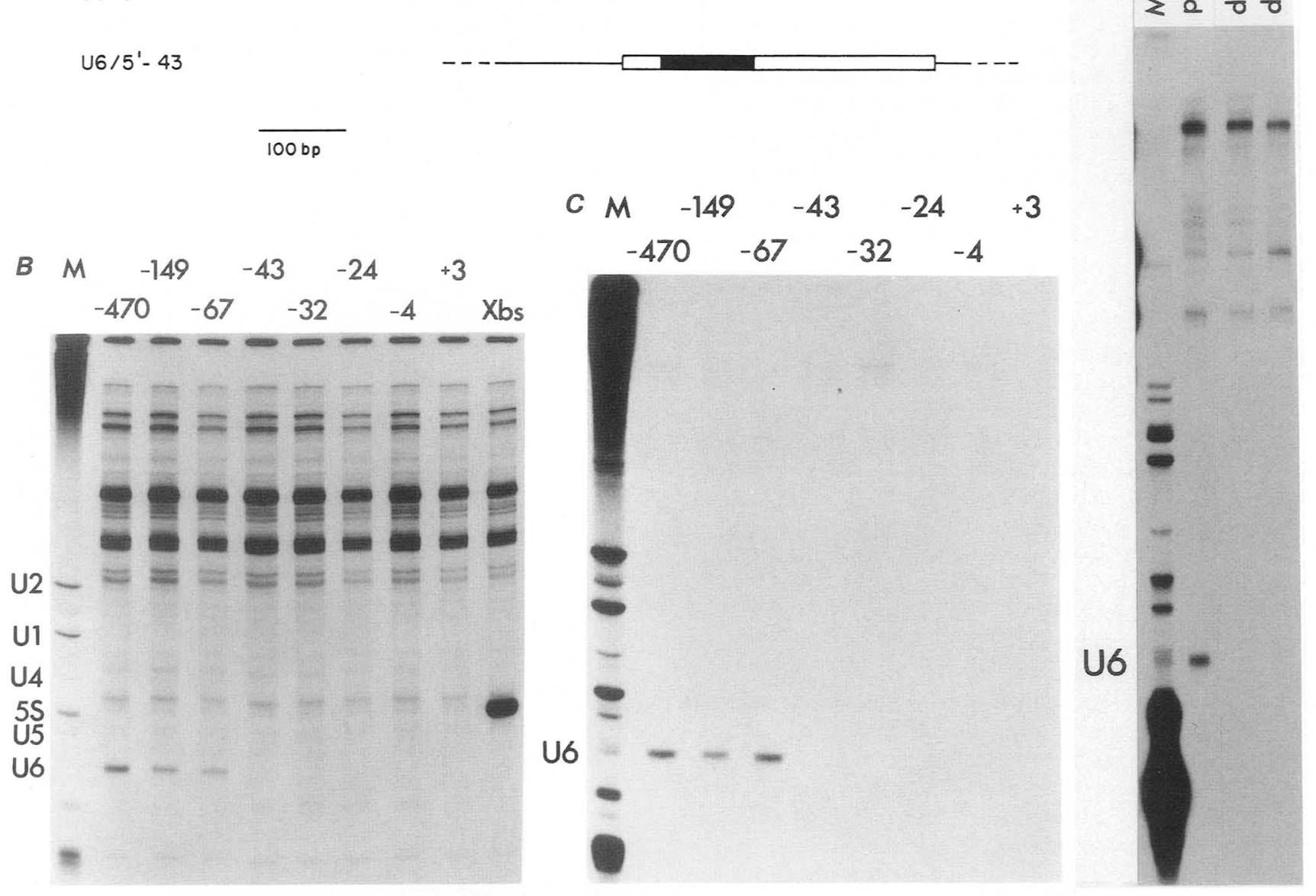

Figure 2. 5'-Flanking sequences promote U6 RNA transcription in vitro. Plasmid DNAs containing deletions of sequences upstream of the U6 RNA start site were used as templates for transcription in a HeLa S100 extract. Each reaction contained $10 \mu \mathrm{g} / \mathrm{ml}$ of U6 DNA and $40 \mu \mathrm{g} / \mathrm{ml}$ of pGEM 1 plasmid containing no insert of human DNA. Following phenol-chloroform extraction and ethanol precipitation, RNA samples were separated by electrophoresis on $10 \%$ polyacrylamide $/ 8.3 \mathrm{M}$ urea gels. $(A)$ Some of the $5^{\prime}$-deletion templates used for in vitro transcription. Restriction sites noted are AvaI (Av), HaeIII (H3), RsaI (Rsa), TaqI (Tq). (B) Total RNA. (Lane M) The pattern of snRNAs from HeLa cells labeled $16 \mathrm{hr}$ with $\left[{ }^{32} \mathrm{P}\right]$-orthophosphate. Numbers over each lane indicate the first nucleotide of 5'-flanking DNA relative to the U6 RNA transcription start site in each of the templates analyzed. (Lane Xbs) The transcription products from a Xenopus borealis somatic 5S RNA gene. $(C)$ RNAs transcribed in reactions containing U6 DNA templates were selected by hybridization to $10 \mu \mathrm{g}$ of nitrocellulose-immobilized M13/U6 DNA. (D) RNAs transcribed from U6 templates with limited deletions in the immediate $5^{\prime}$-flanking region. Two U6 templates were constructed containing deletions in the immediate $5^{\prime}$-flanking region and with an insertion of 8 nucleotides in the form of an XhoI linker (U6/dl $-55,--1$ and Ub/dl $-28,-13$; see Methods for details|. These were used for transcription in a HeLa S100 extract, and U6 RNAs were selected by hybridization as described above. The set of higher molecular weight bands in each lane correspond in size to RNAs transcribed from vector sequences and are not reproducibly recovered by hybridization selection. Lane $M$ contains HeLa snRNAs labeled with [ $\left.{ }^{32} \mathrm{P}\right] \mathrm{pCp}$.

substitution mutants of the U6 maxigene was constructed (Fig. 5A), and each plasmid DNA was transfected into human 293 cells. U6 RNAs were detected by primer extension using an oligonucleotide that hybridizes downstream from the maxigene insertion. The results of such an experiment are shown in Fig. 5B.
The expression of transfected U6 genes ('maxi' in Fig. $5 B$ ) was reduced greater than 10 -fold when DNA from -245 to $-150 \mathrm{bp}$ was deleted. A very low, but quite reproducible, level of maxigene U6 RNA was still synthesized from the $5^{\prime}-149$ template (see also Fig. 6B). Maximal expression of the transfected U6 gene required 


\section{SNRNA PROXIMAL CONTROL ELEMENTS}

\begin{tabular}{|c|c|c|c|}
\hline HUMAN U2 & -62 & TCTCACCGCGACTTGAATGTGGAT & -39 \\
\hline HUMAN U6 & -67 & GC*TACCGTAACTTGAAAGTATY & -44 \\
\hline HUMAN U1 & -63 & AGTGACCGTGTGTGTAAAGAGTGA & -40 \\
\hline
\end{tabular}

Figure 3. The human U6 gene's 5 '-flanking control region has a similar nucleotide sequence to the polymerase II snRNA proximal control element. The human $U 1$ and $U 2$ sequences are from Murphy et al. (1982) and van Arsdell and Weiner (1984), respectively.

5 '-flanking sequences extending to -332 , although the positive effect of the region between -332 and -245 was relatively moderate. Whereas the primer extension results indicated correct initiation from the introduced U6 maxigene, Northern blot analysis of U6 RNA from transfected cells indicated faithful 3 '-end formation as well (data not shown). Measurement of the amounts of the various maxigene plasmid DNAs present at the time of cell harvest demonstrated that differential transfection efficiency and/or DNA stability could not account for the marked reduction of U6 synthesis from the $5^{\prime}$ -149 and 5' -43 templates (middle panel of Fig. 5B).

These results led us to scrutinize the human U6 gene flanking sequence between -245 and -149 . This revealed the presence of an octamer motif from position -222 to -215 (see Fig. 1). This sequence is also present (with two mismatches for U1) at essentially the same location upstream from human U1 and U2 RNA genes, but in the opposite orientation. It is also found at this position and in the 'U6 orientation', in human and chicken U4 RNA genes and a Xenopus U5 gene (Bark et al. 1986; Hoffman et al. 1986; Kazmaier et al. 1987).

\section{The human U6 distal control region is functionally related to but operates differently than the human U2 gene enhancer}

Because of the correlation between the approximate locations and nucleotide sequences of distal control elements for the human U6 RNA gene and the polymerase II-transcribed human U1 and U2 genes, we examined whether they are interchangeable. The human U2 enhancer region was ligated in both orientations to the expression-deficient U6 maxigene/ $/ 5^{\prime}-149$ template (U2 enhancer/maxigene $\mathrm{U} 6$ and flip $\mathrm{U} 2$ enhancer/maxigene U6; see Fig. 6A). In addition, another mutant was constructed in which the entire U6 upstream region from -470 to -149 was inverted in order to examine the orientation and position dependence of the U6 distal control region (B/flip maxigene U6; see Fig. 6A). We also included a template in which the distal U6 region was ligated in its normal orientation but separated by the BamHI linker sequence utilized in the other constructions (designated $\mathrm{B} /$ maxigene $\mathrm{U} 6$ ). The products from primer extension of U6 RNAs from 293 cells transfected with these constructions are shown in Figure 6B. It can be seen that the human U2 gene enhancer, in both orientations, was capable of restoring a significant level of U6 RNA expression when compared to the $5^{\prime}-149$ 'basal' level. However, inverting the orientation of the U6 distal region itself drastically reduced expression of the U6 maxigene (although this level was reproducibly higher than that from the $5^{\prime}-149$ template lacking any distal control region). In addition to changing the orientation of distal sequence elements in these constructions, their location(s) were also altered relative to other promoter elements and the start site of transcription. Nevertheless, it is clear that the U6 gene's own distal element(s) is orientation and/or position dependent.

\section{Discussion}

The transcription apparatus deployed on the human U6 RNA gene involves a polymerase different from that which operates on U1-U5 snRNA genes (Kunkel et al. 1986; Reddy et al. 1987). However, the results of the present study demonstrate a remarkable similarity in the regulatory sequences for these two classes of genes. At least two control elements in the $5^{\prime}$-flanking region of the human U6 RNA gene are necessary for efficient transcription. Within each control region defined by this study are elements having nucleotide sequence similarity and comparable location to previously characterized transcription control elements of vertebrate $\mathrm{Ul}$ and U2 RNA genes. In addition, the human U2 gene enhancer can functionally replace the U6 gene distal control region.

The U6 distal control region (between -245 and -149 ) contains an octamer sequence that is also part of the U2 RNA gene enhancer and of other polymerase II enhancer elements (Mattaj et al. 1985; Singh et al. 1986; Ares et al. 1987; Bohmann et al. 1987) . An octamer motif has been observed in the same orientation at this approximate location for mouse and Xenopus U6 genes (Hoffman et al. 1986; Bark et al. 1987; Krol et al. 1987). Moreover, the transcription of mouse and Xenopus U6 RNA in Xenopus oocytes was responsive to the presence of a distal, octamer-containing sequence, and DNase I footprinting showed protection of the octamer motif (Bark et al. 1987; Carbon et al. 1987). Our transient ex-

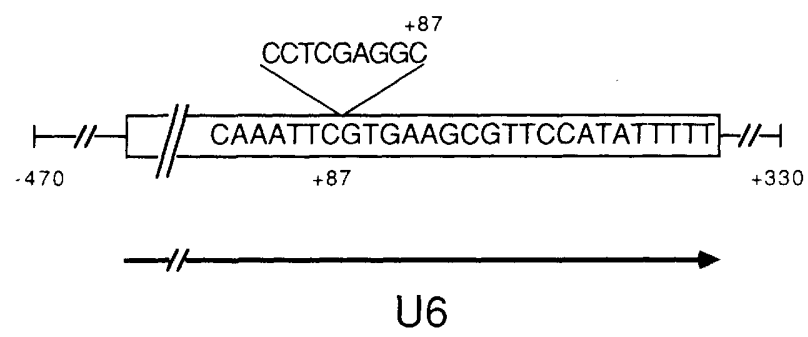

Figure 4. U6 maxigene used for transient expression experiments. A human U6 maxigene was constructed by the insertion of an XhoI linker into the transcribed portion of the U6 gene at nucleotide 87 . The inserted DNA is $9 \mathrm{bp}$, with an extra cytosine nucleotide following the 8-nucleotide $\mathrm{XhoI}$ linker. 
$\mathbf{A}$
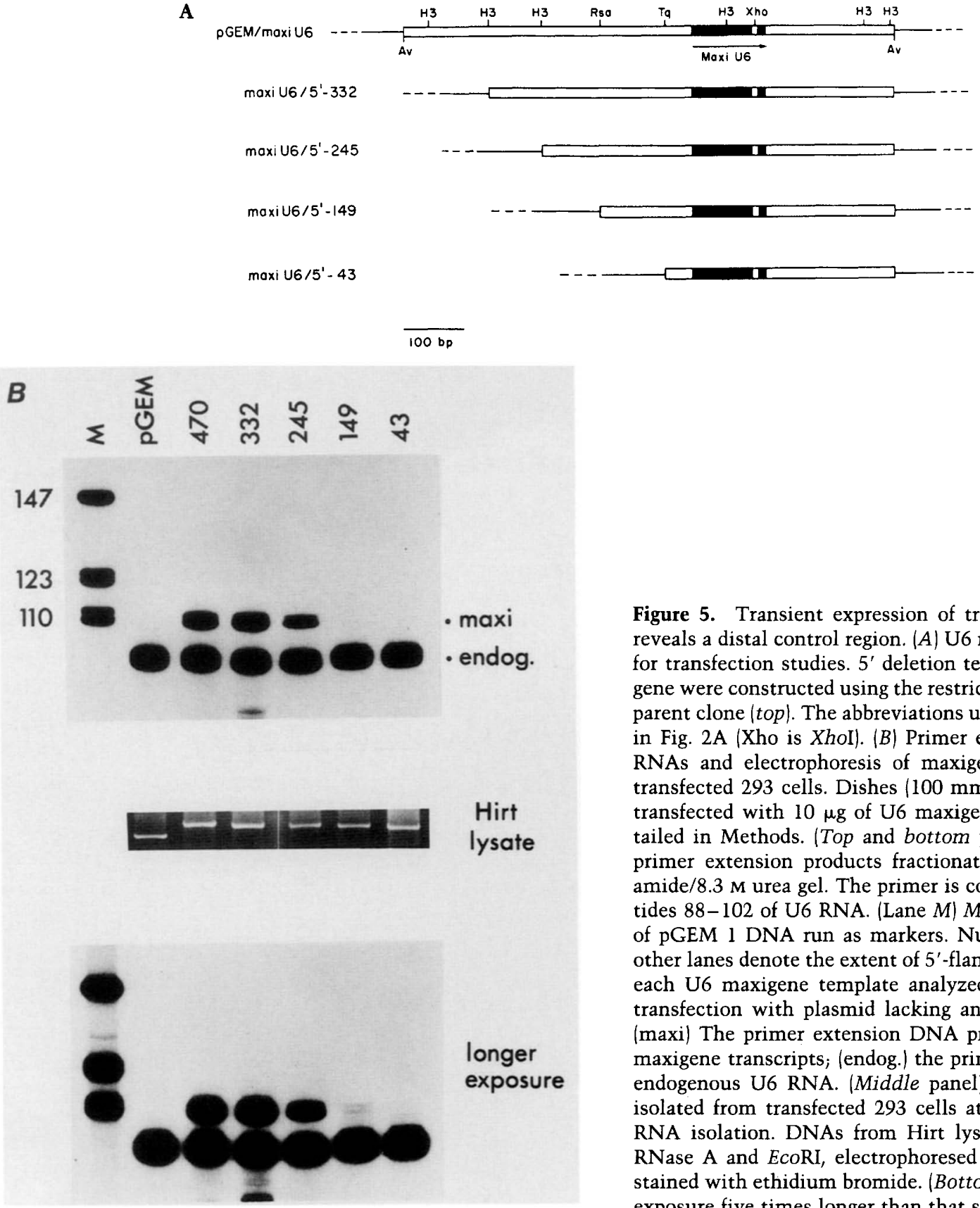

pression results show that the human U6 distal region does not meet the definition of a 'true' enhancer, because the flipped-orientation U6 construction (B/flip U6 maxigene) failed to support efficient expression (Fig. 6B). It is possible that the U6 distal region contains a combination of a 'true' enhancer element and another overriding element that is orientation and/or position dependent.

It is striking that the octamer motif-containing sequence blocks of avian and human U4 RNA genes are present in the same orientation as that reported here for a human U6 gene (Bark et al. 1986; Hoffman et al. 1986), namely the opposite orientation of $\mathrm{U} 1$ and $\mathrm{U} 2$ gene enhancers. U4 and U6 RNAs are assembled into a dimeric

Figure 5. Transient expression of transfected U6 maxigenes reveals a distal control region. (A) U6 maxigene templates used for transfection studies. $5^{\prime}$ deletion templates of the U6 maxigene were constructed using the restriction sites denoted on the parent clone (top). The abbreviations used are the same as those in Fig. 2A (Xho is XhoI). (B) Primer extension analysis of U6 RNAs and electrophoresis of maxigene plasmid DNA from transfected 293 cells. Dishes $(100 \mathrm{~mm})$ of 293 cells were each transfected with $10 \mu \mathrm{g}$ of U6 maxigene plasmid DNA, as detailed in Methods. (Top and bottom panels) U6 RNA-derived primer extension products fractionated on a $10 \%$ polyacrylamide $/ 8.3 \mathrm{M}$ urea gel. The primer is complementary to nucleotides 88-102 of U6 RNA. (Lane $M$ ) MspI restriction fragments of pGEM 1 DNA run as markers. Numbers at the top of the other lanes denote the extent of $5^{\prime}$-flanking sequence present in each U6 maxigene template analyzed; (lane pGEM) A mock transfection with plasmid lacking an insert of human DNA. (maxi) The primer extension DNA product of transfected U6 maxigene transcripts; (endog.) the primer extension product of endogenous U6 RNA. (Middle panel) U6 maxigene plasmids isolated from transfected 293 cells at the time of harvest for RNA isolation. DNAs from Hirt lysates were digested with RNase A and EcoRI, electrophoresed on 1\% agarose gels and stained with ethidium bromide. (Bottom panel) An autographic exposure five times longer than that shown in the top panel.

RNP complex (Bringmann et al. 1984; Hashimoto and Steitz 1984; Rinke et al. 1985), and it is therefore possible that their transcription is coregulated.

In contrast to the transfection experiments, transcription of the U6 RNA gene in a HeLa S100 extract displayed little or no dependence on a distal control region (Fig. 2B,C). It is possible that the $\mathrm{S} 100$ is deficient in nuclear factors that act on this element, or that a functional chromatin configuration does not form in this in vitro system. In addition to the distal control region, the transient expression assay was responsive to a proximal control element between -149 and -43 . The longer exposure of the autoradiograph in Figure $5 B$ (bottom panel) demonstrated a complete lack of transcription from the 
A

maxi U6
B/maxi U6
B/flip maxi U6
U2 enh/maxi U6
flip U2 enh/maxi U6
5'-149/maxi U6
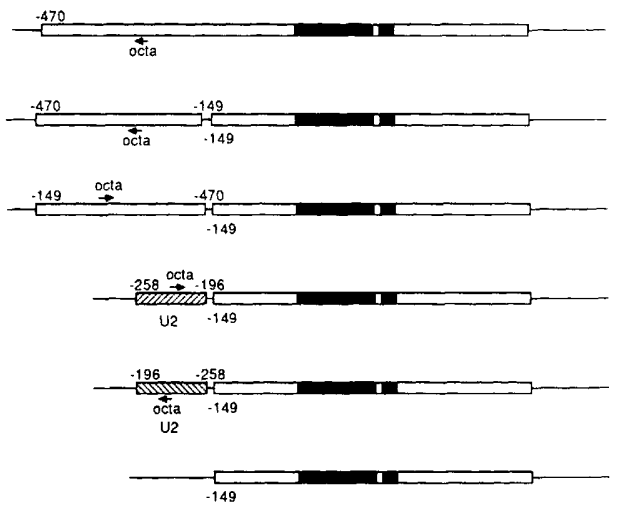
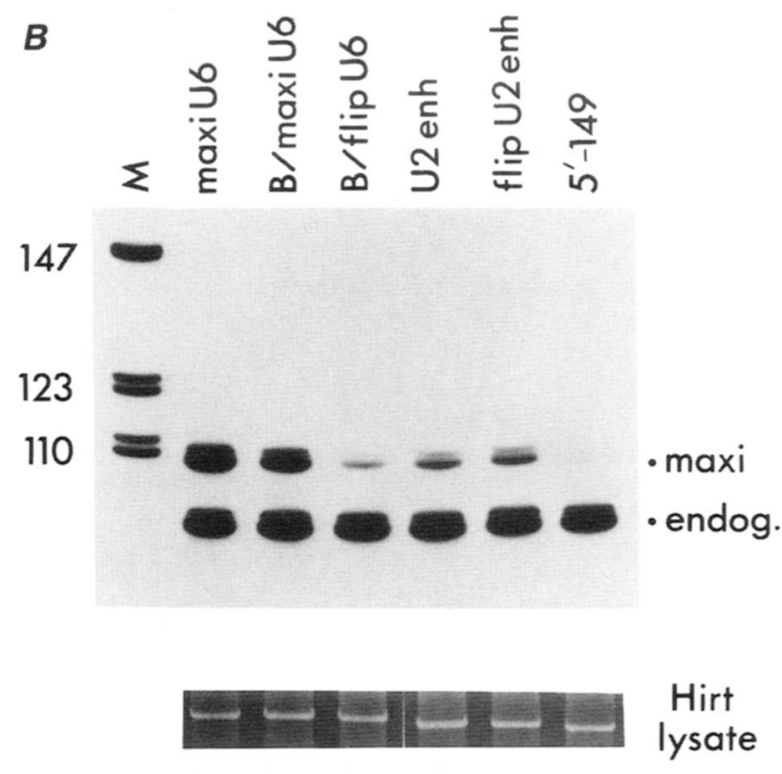

Figure 6. The human U2 enhancer can replace the U6 distal control region to promote elevated transcription. (A) Additional U6 maxigene templates. These constructions were facilitated by the ligation of BamHI linkers to restriction fragments; hence, the B terminology. The approximate position and orientation of the octamer motif is designated by the small arrow. The hatched elements denote $5^{\prime}$-flanking sequence for a human U2 RNA gene. (This diagram is drawn only approximately to scale.) (B) Primer extension analysis of U6 RNAs and direct analysis of maxigene DNAs from transfected cells. Ten micrograms of each template shown in A were transfected into 293 cells, as described in Methods. The particular maxigene construction tested is noted at the top of each lane. (Top panel) U6 primer extension products were electrophoresed on a $10 \%$ polyacrylamide $/ 8.3 \mathrm{~m}$ urea gel. (Bottom panel) U6 maxigene plasmids were isolated by Hirt extraction, as described in Methods, and electrophoresed on $1 \%$ agarose gels.

$5^{\prime}-43$ plasmid, whereas a low but reproducible level of maxi U6 was synthesized from the $5^{\prime}-149$ template.

The 5 '-flanking elements illuminated by this work may constitute only part of the overall control panel for U6 RNA gene transcription. At least two other regions of the U6 gene contain potential transcription regulatory sequences. One is within the transcribed portion of the gene, namely the internal control region characteristic of polymerase III genes. In particular, a nucleotide sequence similar to the A block consensus of eukaryotic tRNA genes is found between positions +48 and +59 of the human U6 gene (Kunkel et al. 1986; see also Fig. 1). However, this A-block-like sequence in the Xenopus U6 gene is not functional (Carbon et al. 1987). In addition, the fact that the U6 maxigene is efficiently transcribed in a HeLa $\mathrm{S} 100$ extract (results not shown) eliminates the continuity of sequence across nucleotide +87 as important for transcription. No internal sequences of the human 7SK RNA gene are required for in vitro transcription by polymerase III (Murphy et al. 1987a).

The TATATA sequence found between -29 and -24 of the human U6 gene (see Fig. 1) is another candidate for a transcription control element. Indeed, our original impetus for undertaking this work was the conservation of a TATA sequence at this approximate position among U6 genes from human, mouse, and Drosophila and a human 7SK RNA gene (Kunkel et al. 1986; Murphy et al. 1986; Das et al. 1987; Reddy et al. 1987). The deletion analyses carried out in the present study uncovered distal elements that would have masked a transcrip- tional effect by the TATA sequence. Mutation of the TATA sequence in the Xenopus U6 gene results in a minor reduction of $\mathrm{U} 6$ synthesis in injected oocytes (Carbon et al. 1987), whereas in vitro transcription of the 7SK gene is severely reduced by a different TATA mutation (Murphy et al. 1987a). Our results with the construction U6/dl $-28,-13$ (Fig. 2D) are consistent with a positive role of the TATA sequence for human U6 transcription.

How might RNA polymerases II and III be responsive to the same DNA control elements? These two polymerases are both multisubunit enzymes, in which some of the smaller subunits are shared (Sentenac 1985). Perhaps the two polymerases contain binding sites for common transcription factors. It is also possible that polymerases II and III react identically to specific chromatin structures conferred by the shared gene control elements.

During the course of this work, we were struck by the surprisingly high level of U6 RNA maxigene expression in transfected 293 cells. In some experiments, the amount of maxi U6 RNA was almost equal to the amount of endogenous U6 RNA. In contrast, expression of the U6 maxigene in transfected HeLa cells was barely detectable (results not shown). Transfected 293 cells stabilize much higher amounts of plasmid DNA compared with other cell lines (Alwine 1985). It is also possible that the polymerase III-transcribed U6 genes are especially responsive to the constitutively expressed adenovirus E1A gene product in 293 cells (Aiello et al. 1979). A 
correlation has been previously reported between E1A expression and elevated activity of transcription factor IIIC (Hoeffler and Roeder 1985; Yoshinaga et al. 1986). Perhaps the high level of U6 RNA expression in 293 cells reflects the operation of polymerase III-responsive control element(s) of this gene.

\section{Methods}

Cells

HeLa cells were maintained in suspension culture, as described previously (Pederson 1972). 293 cells were grown as monolayers in Dulbecco-modified Eagle's medium with $10 \%$ fetal calf serum.

\section{DNA constructions}

The parent DNA used for the constructions described below was pGEM/U6 (Kunkel et al. 1986), which contains approximately 800 bp of human DNA inserted into the SmaI site of the pGEM 1 vector (Promega Biotec, Madison, WI). Two of the deletion-substitution templates used for in vitro transcription (termed 5' -149 and 5' -43 in Fig. 2) were constructed by excision of the desired fragment at an appropriate restriction site and ligation into pGEM 1. The other deletions were constructed by controlled exonuclease III digestion after opening the pGEM/U6 plasmid by PstI + BamHI double digestion (Henikoff 1984).

A linker-scanning protocol was used to construct the deletion templates $\mathrm{U} 6 / \mathrm{dl}-55,-1$ and $\mathrm{U} 6 / \mathrm{dl}-28,-13.5^{\prime}$ nucleotides were removed by exonuclease III $+\mathrm{S} 1$ nuclease treatment after BamHI digestion, and appropriately sized DNA fragments were gel purified after Xhol linker addition and EcoRI digestion. Similarly, $3^{\prime}$ nucleotides were trimmed by sequential treatment with EcoRI, exonuclease III, S1 nuclease, XhoI linker ligation, BamHI and agarose gel purification. DNA fragments containing $5^{\prime}$ deletions and those containing $3^{\prime}$ deletions were then ligated together at the XhoI linker and inserted into a pGEM 2 vector doubly cut with BamHI and EcoRI.

The U6 maxigene was constructed from two Xhol linker mutants generated in the protocol described above. One plasmid $(\mathrm{U} 6 / \mathrm{dl}+88,+145)$ was restricted with $\mathrm{XhoI}$ and $E c o \mathrm{RI}$, and the large fragment $(\sim 3400 \mathrm{bp})$ was purified on a preparative agarose gel. The other plasmid $(\mathrm{Ub} / \mathrm{dl}+73,+86)$ was cut with $X$ hoI and EcoRI, and the smaller fragment $(\sim 260 \mathrm{bp})$ was gel purified. The two purified fragments were then ligated, resulting in the pGEM/maxi U6 plasmid. 5' deletion-substitution templates were then generated by cutting at appropriate restriction sites, agarose gel purification of the desired DNA fragment, and ligation into a pGEM 1 vector.

U6 maxigene templates in which the distal control region's orientation was inverted or substituted with the human U2 gene enhancer were constructed by ligation at the BamHI site in the polylinker sequence just upstream of the maxi $U 6 / 5^{\prime}$ -149 insert (hence, the ' $B$ ' terminology, for $B a m$ ). To generate the $\mathrm{B} /$ maxigene $\mathrm{U} 6$ and $\mathrm{B} / \mathrm{flip}$ maxigene U6 plasmids, pGEM/ U6 was cut with RsaI, and BamHI linkers were ligated. The DNA was then restricted at the unique BamHI site in the polylinker, and the $\sim 330$-bp fragment containing the U6 upstream region from -470 to -149 was purified by agarose gel electrophoresis. This fragment was ligated to plasmid maxigene U6/5' -149, which had been restricted at the BamHI site and treated with calf intestine alkaline phosphatase. Plasmids U2 en- hancer/maxigene U6 and flip U2 enhancer/maxigene U6 were constructed by a similar strategy. Plasmid pSPP2UH (a human U2 gene plasmid containing the HincII $(-258) / P s t I(\sim+1200)$ fragment (Westin et al. 1984b) ligated into the HincII/PstI sites of pSP64 was cut with AvaI and modified by addition of BamHI linkers. After the DNA was cut at the BamHI site of the polylinker, a $\sim 70$-bp fragment containing the U2 enhancer from -258 to -198 was purified by gel electrophoresis and ligated at the BamHI site of maxigene U6/5' -149 .

All plasmid constructions were verified by restriction enzyme digestion and dideoxy sequencing.

\section{Transcription in a HeLa cell S100 extract}

Preparation of HeLa cell S100 extract, transcription, hybridization selection, and electrophoresis on $10 \%$ polyacrylamide $/ 8.3$ M urea gels were carried out as described (Kunkel et al. 1986), with the modifications noted in the figure legends.

\section{Transfections and RNA isolation}

Before transfection, 293 cells were plated subconfluently in $100-\mathrm{mm}$ dishes and cultured for approximately $24 \mathrm{hr}$. Ten micrograms of each plasmid DNA were incorporated into calcium phosphate precipitates and transfected (Hernandez 1985), except that the DMSO shock was omitted. Cells were harvested $42-50 \mathrm{hr}$ after transfection, and the suspension was divided into two equal parts. One portion was broken by homogenization in hypotonic buffer (10 $\mathrm{mm} \mathrm{NaCl}, 1.5 \mathrm{mM} \mathrm{MgCl}_{2}, 10 \mathrm{~mm}$ Tris at $\mathrm{pH}$ 7.4). Homogenates were adjusted to $0.1 \mathrm{M} \mathrm{NaCl}$, sonicated, and centrifuged for $3 \mathrm{~min}$ in an Eppendorf microfuge. The supernatants were then adjusted to $0.3 \%$ SDS and 100 $\mu \mathrm{g} / \mathrm{ml}$ Proteinase $\mathrm{K}$ and incubated for $15 \mathrm{~min}$ at $20^{\circ} \mathrm{C}$. After phenol/chloroform extraction and ethanol precipitation, RNA samples were dissolved in water. To control for differential transfection efficiency or DNA stability, the other portion of cells was subjected to Hirt lysis (Hirt 1967). Equal volumes of Hirt supernatants were extracted once with phenol/chloroform and precipitated with ethanol. Nucleic acids were digested with RNase A $(50 \mu \mathrm{g} / \mathrm{ml})$ and EcoRI and electrophoresed on $1 \%$ agarose gels.

\section{Primer extension}

A U6-complementary oligonucleotide (TATGGAACGCTTCAC) was labeled with $\left[\gamma^{-32} \mathrm{P}\right] \mathrm{ATP}$ and T4 polynucleotide kinase and annealed to RNA samples in $80 \%$ formamide, $0.4 \mathrm{M} \mathrm{NaCl}, 66$ $\mathrm{mM}$ PIPES (pH 6.6), and $1 \mathrm{~mm}$ EDTA at $37^{\circ} \mathrm{C}$ for $5 \mathrm{hr}$. After precipitation of nucleic acids with ethanol, primer extension was carried out in the presence of $83 \mathrm{~mm}$ Tris $(\mathrm{pH} 8.5), 8.3 \mathrm{~mm}$ $\mathrm{MgCl}_{2}, 10 \mathrm{mM} \mathrm{KCl}, 2 \mathrm{~mm}$ each dNTP, $1 \mathrm{~mm} \mathrm{DTT}, 40 \mu \mathrm{g} / \mathrm{ml}$ actinomycin $\mathrm{D}$, and $4-5$ units of AMV reverse transcriptase at $45^{\circ} \mathrm{C}$ for $1 \mathrm{hr}$. The reactions were quenched by adding EDTA to $15 \mathrm{~mm}$ and sodium acetate to $0.2 \mathrm{M}$. Nucleic acids were precipitated with ethanol and electrophoresed on $10 \%$ polyacrylamide/8.3 $\mathrm{M}$ urea gels.

\section{Acknowledgments}

We thank John Goodchild for synthesizing oligonucleotides in the Worcester Foundation's central facility, supported by NIH cancer center core grant P30-12708, Linda Malkas for 293 cells, and Ann Kleinschmidt for providing the plasmid pSPP2UH. We are grateful to Ann Kleinschmidt, Sandra Mayrand, Ronald Patterson, and Jeffrey Patton for advice and criticism throughout 
the course of this work. We also acknowledge the competent secretarial assistance of Jacqueline Foss. This research was supported by National Institutes of Health (NIH) grant GM-21595 and a NIH postdoctoral fellowship to G.R.K. (GM-09403).

\section{References}

Aiello, L., R. Guilfoyle, K. Huebner, and R. Weinmann. 1979. Adenovirus 5 DNA sequences present and RNA sequences transcribed in transformed human embryo kidney cells (HEK-Ad-5 or 293). Virology 94: 460-469.

Alwine, J.C. 1985. Transient gene expression control: Effects of transfected DNA stability and trans-activation by viral early proteins. Mol. Cell. Biol. 5: 1034-1042.

Ares, M., Jr., J.-S. Chung, L. Giglio, and A.M. Weiner. 1987. Distinct factors with Spl and NF-A specificities bind to adjacent functional elements of the human U2 snRNA gene enhancer. Genes Dev. 1: 808-817.

Bark, C., P. Weller, J. Zabielski, and U. Pettersson. 1986. Genes for human U4 small nuclear RNA. Gene 50: 333-344.

Bark, C., P. Weller, J. Zabielski, L. Janson, and U. Pettersson. 1987. A distinct enhancer element is required for polymerase III transcription of a U6 RNA gene. Nature 328: 356-359.

Bohmann, D., W. Keller, T. Dale, H.R. Scholer, G. Tebb, and I.W. Mattaj. 1987. A transcription factor which binds to the enhancers of SV40, immunoglobulin heavy chain, and U2 snRNA genes. Nature 325: 268-272.

Bringmann, P., B. Appel, J. Rinke, R. Reuter, H. Theissen, and R. Luhrmann. 1984. Evidence for the existence of snRNAs $\mathrm{U} 4$ and $\mathrm{U} 6$ in a single ribonucleoprotein complex and for their association by intermolecular base pairing. EMBO $\mathrm{J}$. 3: $1357-1363$.

Carbon, P., S. Murgo, J.-P. Ebel, A. Krol, G. Tebb, and I.W. Mattaj. 1987. A common octamer motif binding protein is involved in the transcription of U6 snRNA by RNA polymerase III and U2 snRNA by RNA polymerase II. Cell 51: $71-79$.

Ciliberto, G., R. Buckland, R. Cortese, and L. Philipson. 1985. Transcription signals in embryonic Xenopus laevis U1 RNA genes. EMBO /. 4: 1537-1543.

Ciliberto, G., F. Palla, G. Tebb, I.W. Mattaj, and L. Philipson. 1987. Properties of a U1 RNA enhancer-like sequence. $\mathrm{Nu}$ cleic Acids Res. 15: 2403-2416.

Das, G., D. Henning, and R. Reddy. 1987. Structure, organization and transcription of Drosophila U6 small nuclear RNA genes. J. Biol. Chem. 262: 1187-1193.

Epstein, P., R. Reddy, D. Henning, and H. Busch. 1980. The nucleotide sequence of nuclear U6 (4.7S) RNA. I. Biol. Chem. 255: 8901-8906.

Falkner, F.G. and H.G. Zachau. 1984. Correct transcription of an immunoglobulin kappa gene requires an upstream fragment containing conserved sequence elements. Nature 310: $71-74$.

Hashimoto, C. and J.A. Steitz. 1984. U4 and U6 RNAs coexist in a single small nuclear ribonucleoprotein particle. Nucleic Acids Res. 12: 3283-3293.

Henikoff, S. 1984. Unidirectional digestion with exonuclease III creates targeted breakpoints for DNA sequencing. Gene 28: $351-359$.

Hernandez, N. 1985. Formation of the $3^{\prime}$ end of Ul snRNA is directed by a conserved sequence located downstream of the coding region. $E M B O J .4: 1827-1837$.

Hirt, B. 1967. Selective extraction of polyoma DNA from infected mouse cell cultures. I. Mol. Biol. 26: 365-369.

Hoeffler, W.K. and R.G. Roeder. 1985. Enhancement of RNA polymerase III transcription by the ElA gene product of adenovirus. Cell 41: 955-963.

Hoffman, M.L., G.M. Korf, K.J. McNamara, and W.E. Stumph. 1986. Structural and functional analysis of chicken U4 small nuclear RNA genes. Mol. Cell. Biol. 6: 3910-3919.

Jensen, E.G., P. Hellung-Larsen, and S. Frederiksen. 1979. Synthesis of low molecular weight RNA components A, C and $\mathrm{D}$ by polymerase II in $\alpha$-amanitin resistant hamster cells. Nucleic Acids Res. 6: 321-330.

Kazmaier, M., G. Tebb, and I.W. Mattaj. 1987. Functional characterization of $X$. laevis U5 snRNA genes. EMBO $J$. 6: 3071-3078.

Krol, A., E. Lund, J.E. Dahlberg. 1985. The two embryonic U1 RNA genes of Xenopus laevis have both common and genespecific transcription signals. EMBO I. 4: 1529-1535.

Krol, A., P. Carbon, J.-P. Ebel, and B. Appel. 1987. Xenopus tropicalis U6 snRNA genes transcribed by pol III contain the upstream promoter elements used by pol II dependent U snRNA genes. Nucleic Acids Res. 15: 2463-2478.

Kunkel, G.R. and T. Pederson. 1985. Transcription boundaries of Ul small nuclear RNA. Mol. Cell. Biol. 5: 2332-2340.

Kunkel, G.R., R.L. Maser, J.P. Calvet, and T. Pederson. 1986. U6 small nuclear RNA is transcribed by RNA polymerase III. Proc. Natl. Acad. Sci. 83: 8575-8579.

Mangin, M., M. Ares, Jr., and A.M. Weiner. 1986. Human U2 small nuclear RNA genes contain an upstream enhancer. EMBO I. 5: 987-995.

Maniatis, T. and R. Reed. 1987. The role of small nuclear ribonucleoprotein particles in pre-mRNA splicing. Nature 325: 673-678.

Mattaj, I.W., S. Lienhard, J. Jiricny, and E.M. De Robertis. 1985. An enhancer-like sequence within the Xenopus U2 gene promoter facilitates the formation of stable transcription complexes. Nature 316: 163-167.

Murphy, S., C. DiLiegro, and M. Melli. 1987a. The in vitro transcription of the 7SK RNA gene by RNA polymerase III is dependent only on the presence of an upstream promoter. Cell 51: 81-87.

Murphy, S., M. Tripodi, and M. Melli. 1986. A sequence upstream from the coding region is required for the transcription of the 7SK RNA genes. Nucleic Acids Res. 14: 92439260.

Murphy, J.T., R.R. Burgess, J.E. Dahlberg, and E. Lund. 1982. Transcription of a gene for human U1 small nuclear RNA. Cell 29: 265-274.

Murphy, J.T., J.T. Skuzeski, E. Lund, T.H. Steinberg, R.R. Burgess, and J.E. Dahlberg. 1987b. Functional elements of the human Ul RNA promoter. Identification of five separate regions required for efficient transcription and template competition. J. Biol. Chem. 262: 1795-1803.

Parslow, T.G., D.L. Blair, W.J. Murphy, and D.K. Granner. 1984. Structure of the 5' ends of immunoglobulin genes: A novel conserved sequence. Proc. Natl. Acad. Sci. 81: 2650-2654.

Pederson, T. 1972. Chromatin structure and the cell cycle. Proc. Natl. Acad. Sci. 69: 2224-2228.

Reddy, R., D. Henning, G. Das, M. Harless, and D. Wright. 1987. The capped U6 small nuclear RNA is transcribed by RNA polymerase III. $J$. Biol. Chem. 262: 75-81.

Rinke, J., B. Appel, M. Digweed, and R. Luhrmann. 1985. Localization of a base-paired interaction between small nuclear RNAs U4 and U6 in intact U4/U6 ribonucleoprotein particles by psoralen cross-linking. I. Mol. Biol. 185: 721-731.

Ro-Choi, T.S., N.B.K. Raj, L.M. Pike, and H. Busch. 1976. Effects of $\alpha$-amanitin, cycloheximide, and thioacetamide on low molecular weight nuclear RNA. Biochemistry 15: $3823-3828$. 
Roop, D.R., P. Kristo, W.E. Stumph, M.-J. Tsai, and B.W. O'Malley. 1981. Structure and expression of a chicken gene coding for U1 RNA. Cell 23: 671-680.

Sentenac, A. 1985. Eukaryotic RNA polymerases. CRC Crit. Rev. Biochem. 18: 31-90.

Sharp, P.A. 1987. Splicing of messenger RNA precursors. Science 235: 766-771.

Singh, H., R. Sen, D. Baltimore, and P.A. Sharp. 1986. A nuclear factor that binds to a conserved sequence motif in transcriptional control elements of immunoglobulin genes. Nature 319: 154-158.

Sive, H.L. and R.G. Roeder. 1986. Interaction of a common factor with conserved promoter and enhancer sequences in histone $\mathrm{H} 2 \mathrm{~B}$, immunoglobulin and U2 small nuclear RNA genes. Proc. Natl. Acad. Sci. 83: 6382-6386.

Skuzeski, J.M., E. Lund, J.T. Murphy, T.H. Steinberg, R.R. Burgess, and J.E. Dahlberg. 1984. Synthesis of human Ul RNA. II. Identification of two regions of the promoter essential for transcription initiation at position +1 . J. Biol. Chem. 259: 8345-8352.

van Arsdell, S.W. and A.M. Weiner. 1984. Human genes for U2 small nuclear RNA are tandemly repeated. Mol. Cell. Biol. 4: $492-499$.

Weil, P.A., J. Segall, B. Harris, S. Ng, and R.G. Roeder. 1979. Faithful transcription of eukaryotic genes by RNA polymerase III in systems reconstituted with purified DNA templates. J. Biol. Chem. 254: 6163-6173.

Westin, G., E. Lund, J.T. Murphy, U. Pettersson, and J.E. Dahlberg. 1984a. Human U2 and U1 RNA genes use similar transcription signals. EMBO J. 3: 3295-3301.

Westin, G., J. Zabielski, K. Hammarstrom, H.-J. Monstein, C. Bark, and U. Pettersson. 1984b. Clustered genes for human U2 RNA. Proc. Natl. Acad. Sci. 81: 3811-3815.

Yoshinaga, S., N. Dean, M. Han, and A.J. Berk. 1986. Adenovirus stimulation of transcription by RNA polymerase III: Evidence for an ElA-dependent increase in transcription factor IIIC concentration. EMBO I. 5: 343-354. 


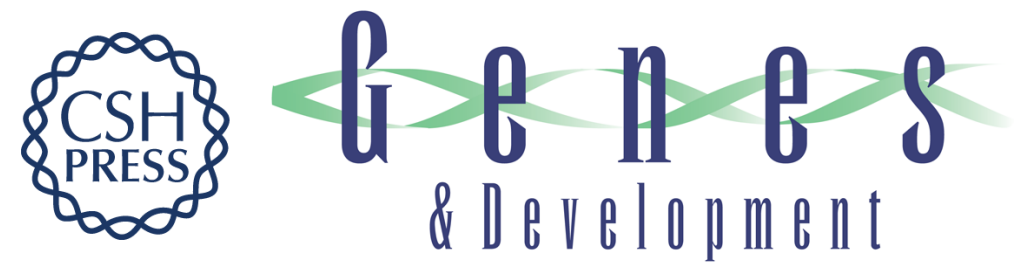

\section{Upstream elements required for efficient transcription of a human U6 RNA gene resemble those of U1 and U2 genes even though a different polymerase is used.}

G R Kunkel and T Pederson

Genes Dev. 1988, 2:

Access the most recent version at doi:10.1101/gad.2.2.196

References This article cites 48 articles, 17 of which can be accessed free at:

http://genesdev.cshlp.org/content/2/2/196.full.html\#ref-list-1

License

Email Alerting Receive free email alerts when new articles cite this article - sign up in the box at the top

Service right corner of the article or click here.

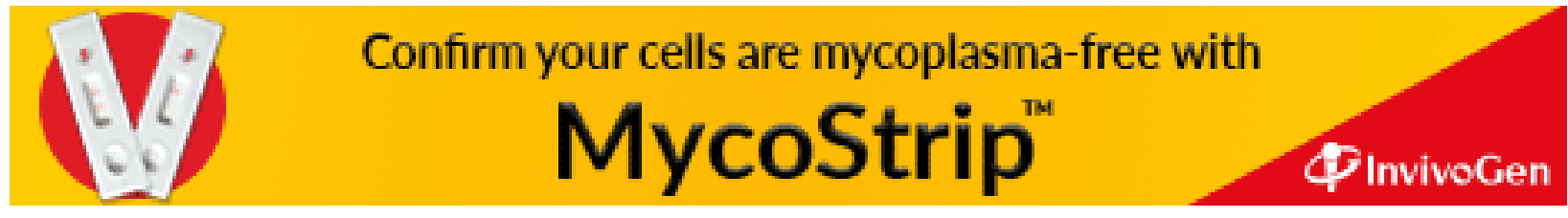

